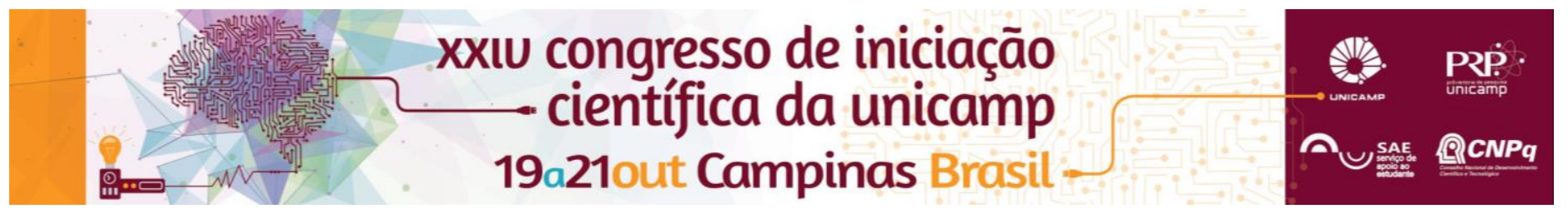

\title{
Arte/Cidade II - A Cidade e Seus Fluxos: Uma Leitura Tipológica de Suas Intervenções Urbanas
}

\author{
Marta L. Montagnana*, Marco Antônio A. do Valle.
}

\section{Resumo}

Estudo aprofundado acerca das intervenções urbanas de Guto Lacaz, Rubens Mano e Tadeu Knudsen durante o movimento Arte/Cidade II, denominado A Cidade e Seus Fluxos, ocorrido em 1994 na cidade de São Paulo. A edição se diferenciou pela localização das ações que se deram em diversos espaços da zona central da cidade, inseridas no cotidiano paulistano. A pesquisa se destinou a uma leitura tipológica dessas intervenções a fim de traçar uma análise crítica

comparativa

em

relação

ao

conjunto.

Palavras-chave

Intervenção Urbana, Arte/Cidade II, Arte Contemporânea.

\section{Introdução}

Arte/Cidade II - A Cidade e Seus Fluxos foi um projeto com curadoria de Nelson Brissac, composto por intervenções artísticas, que ocorreu em 1994 na região central da cidade de São Paulo. Sua característica de imersão naquela centralidade do Vale do Anhangabaú, sem um espaço delimitado, mas que possibilitava a criação de trajetos, foi extraordinariamente atualizadora das questões artísticas para a produção brasileira. Além disso, foi a primeira e maior proposta de intervenções urbanas do país. Dentre suas obras, estiveram Periscópio de Guto Lacaz, Detector de Ausências de Rubens Mano e Quanto Pesa Vale de Tadeu Knudsen, objetos dessa pesquisa em que compõem um conjunto tipológico.

\section{Resultados e Discussão}

Durante a pesquisa, discutiram-se e chegaram às seguintes informações.

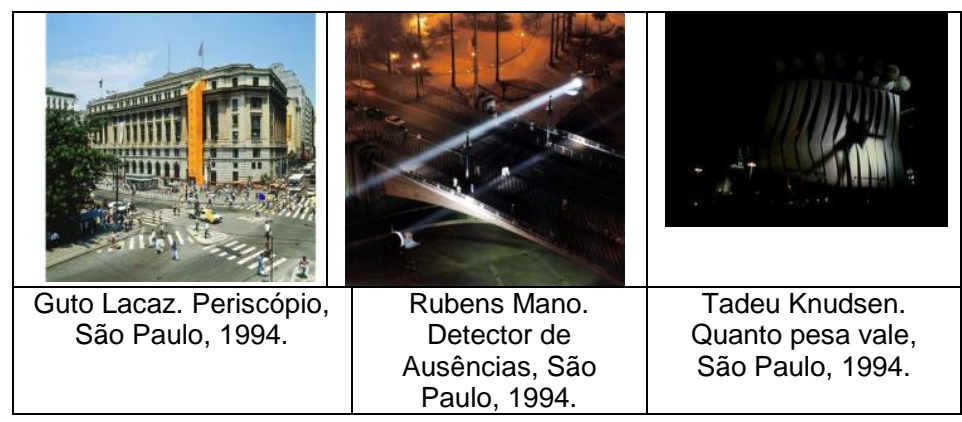

A obra de Guto Lacaz possibilitou através de um jogo de espelhos uma "comunicação visual entre dois planos, um trânsito instantâneo de um nível a outro, alterando o horizonte da cidade"1, de forma a proporcionar uma observação em tempo e tamanho reais de outra perspectiva, em uma inquietude a respeito das relações de escalas, tempo e transporte, evidenciando a relação dessa obra com a arquitetura, com o espaço urbano, a fotografia e com os mapas.

Rubens Mano, realizou a instalação de dois refletores de luz, no Viaduto do Chá, que projetam em sombra, em recorte, a silhueta dos passantes na cidade sem realizar qualquer tipo de registro, "são uma constatação de seu anonimato. (...)Esses holofotes são, a um só tempo, uma homenagem lírica à luz e um alerta para a fugacidade dessa presença. (...)"2.A relação com a fotografia e a escala de representação relacionada ao espaço urbano são questões que contribuem para a análise do grupo tipológico.

Tadeu Knudsen faz uma intervenção que retoma elementos do cinema, em que um refletor projeta a imagem, dos que se exibirem em um palco público, em dimensão ampliada, rivalizando com as construções ao redor. "Assim como o cinema era originalmente destinado a mostrar o rosto das pessoas comuns, esta encenação traz os transeuntes da grande cidade. Expostos, porém, no anonimato das sombras"3.

\section{Conclusões}

Com essas informações reunidas, define-se o conjunto tipológico. Dentre todas as intervenções do projeto, essas três reúnem características comuns que permeiam as obras de forma intrínseca: a relação entre imagem e a dimensão urbana. Nesse sentido, Guto Lacaz faz transposições de imagens - como ocorre em técnicas virtuais - de forma a brincar com as possíveis perspectivas da cidade; associando-as ainda às relações interpessoais e fluxos ligados à ela. Enquanto Rubens Mano trabalha a projeção de imagem ligada à fotografia na dimensão do urbano, equiparando o anonimato aos aspectos da cidade; coloca a fotografia enquanto técnica, aumentando seu alcance e debatendo seus fins. Já Tadeu Knudsen constrói sua obra retomando os cinemas de rua e a céu aberto que reuniam as pessoas na segunda metade do século $X X$, colocando dessa vez também o público como atuantes e projetando-os sem identidade, assim como Mano.

\section{Agradecimentos}

Agradeço ao Prof. Dr. Marco do Valle pela orientação. Este projeto recebeu apoio do Programa Institucional de Bolsas de Iniciação Científica e Tecnológica CNPQUnicamp.

1 PEIXOTO, N.B. (org.), Intervenções Urbanas: Arte/Cidade, catálogo, Nelson Brissac Peixoto. - São Paulo: Editora SENAC São Paulo, 2002. Pág.77

2 PEIXOTO, Nelson Brissac. Arte/Cidade: A Cidade e Seus Fluxos. São Paulo, Editora Marca D’Água. 1994, pág18

3 PEIXOTO, Nelson. A cidade e seus fluxos. Disponível em <http://www.pucsp.br/artecidade/novo/ac2/30.htm> Acesso em: 17 de dezembro de 2015 . 